\title{
A cross sectional survey of the side effects of antiretroviral (ARV) on HIV outpatients using the Naranjo algorithm
}

\section{Survei cross sectional efek samping obat antiretroviral (ARV) pada pasien HIV rawat jalan dengan algoritma Naranjo}

\author{
Oki Nugraha Putra* \\ Departemen Farmasi Klinik, Program Studi Farmasi, Universitas Hang Tuah, Surabaya \\ *Corresponding author: oki.nugraha@hangtuah.ac.id
}

\begin{abstract}
Background: The main modality in HIV patients is the administration of long-term antiretroviral therapy (ARV). One of the problems in the use of ARV therapy is the side effects that can reduce patient compliance with the medication, thus potentially leading to treatment failure.

Objective: This study aims to examine the side effects and causality of the use of ARV among HIV outpatients at the VCT Clinic of H.S. Samsoeri Mertojoso Bhayangkara Hospital Surabaya.

Methods: This research was a prospective observational study with a cross-sectional design. The side effect data were taken from HIV patients through interviews using the Naranjo algorithm. HIV patients who met the inclusion criteria were included in the study samples that employed consecutive sampling. This research was conducted from January to March 2020.

Results: There were 72 HIV outpatients who met the inclusion criteria. The most frequently found opportunistic infections in HIV patients were tuberculosis and pneumocystis pneumonia. The results showed that the most common side effects experienced by the patients were dizziness (43\%), nausea and vomiting (31\%), and rash $(11 \%)$ with the highest Naranjo score being the probable category with $86 \%$. The Naranjo score in HIV patients with opportunistic infections and comorbidities was significantly smaller than that in HIV patients without opportunistic infections or comorbidities tested with independent t-test $(\mathrm{P}<0.05)$.

Conclusion: The side effects in HIV patients while undergoing treatment with antiretroviral therapy were classified as minor and the cause of the side effects that occurred was the probable category of ARV therapy.
\end{abstract}

Keywords: HIV patients, antiretroviral, side effects, Naranjo algorithm

\section{Intisari}

Pendahuluan: Modalitas utama pada pasien HIV ialah pemberian terapi antiretroviral (ARV) dalam jangka waktu yang panjang. Salah satu masalah yang timbul dari penggunaan terapi ARV ialah efek samping obat yang dapat menurunkan kepatuhan pasien dalam minum obat sehingga berpotensi menimbulkan gagal pengobatan.

Tujuan: Penelitian ini bertujuan untuk mengkaji efek samping dan kausalitasnya pada penggunaan ARV pada pasien HIV rawat jalan di Poli VCT, Rumah Sakit Bhayangkara H.S. Samsoeri Mertojoso Surabaya.

Metode: Penelitian ini merupakan penelitian observasional prospektif dengan desain penelitian cross-sectional. Data efek samping diambil dari pasien HIV dengan wawancara menggunakan algoritma naranjo. Pasien HIV yang memenuhi kriteria inklusi dimasukkan sebagai sampel penelitian menggunakan jenis consecutive sampling. Penelitian ini dilakukan pada bulan Januari hingga Maret 2020.

Hasil: Didapatkan 72 pasien HIV rawat jalan yang memenuhi kriteria inklusi. Infeksi oportunistik terbanyak yang ditemukan pada pasien HIV ialah tuberkulosis dan Pneumocystis pneumonia. Hasil penelitian menunjukan kejadian efek samping yang paling banyak dialami 
pasien adalah pusing (43\%), mual dan muntah (31\%), ruam (11\%) dengan skor Naranjo terbanyak berada pada kategori probable sebesar $86 \%$. Hasil skor Naranjo pada pasien HIV dengan infeksi oportunistik maupun dengan penyakit penyerta lebih kecil secara signifikan dibandingkan dengan pasien HIV tanpa infeksi oportunistik maupun tanpa penyakit komorbid dengan independent $t$-test $(\mathrm{P}<0,05)$.

Kesimpulan: Efek samping yang ditemukan pada pasien HIV selama menjalani pengobatan dengan obat antiretroviral merupakan jenis efek samping minor dan penyebab efek samping yang terjadi diduga diakibatkan oleh obat ARV dalam kategori probable.

Kata kunci: Pasien HIV, antiretroviral, efek samping, algoritma Naranjo.

\section{Pendahuluan}

HIV (Human Immunodeficiency Virus) adalah virus yang menyerang atau menginfeksi sel darah putih khususnya sel CD4+ yang menyebabkan turunnya kekebalan tubuh manusia dan dapat menyebabkan komplikasi infeksi oportunistik (Dipiro et al., 2017). Acquired Immuno Deficiency Syndrome (AIDS) adalah suatu kumpulan gejala berkurangnya kemampuan imunitas tubuh yang disebabkan oleh masuknya virus HIV (Kemenkes, 2014). Perbedaan mendasar antara HIV dan AIDS ialah terletak pada jumlah $\mathrm{CD}^{+}$, dimana pada HIV jumlah $\mathrm{CD} 4^{+} \geq 500 \mathrm{sel} / \mathrm{mm}^{3}$, sedangkan pada AIDS jumlah CD4+ $<200 \mathrm{sel} / \mathrm{mm}^{3}$ (Dipiro et al., 2015). Kasus HIV di Indonesia dilaporkan dari tahun 2005 sampai dengan tahun 2018 mengalami kenaikan tiap tahunnya. Jumlah kumulatif infeksi HIV yang dilaporkan pada tahun 2018 yakni sebanyak 46.569 kasus. Provinsi Jawa Timur menempati urutan pertama dengan jumlah HIV terbanyak sebesar 8.608 kasus dan Kota Surabaya menempati posisi pertama di Jawa Timur dengan jumlah HIV terbanyak sebesar 629 kasus (Kemenkes, 2019). Modalitas utama untuk tatalaksana pasien HIV/AIDS ialah pemberian obat antiretroviral (ARV) yang bertujuan untuk menekan replikasi virus dan viral load sehingga dapat memperpanjang usia harapan hidup pasien (Kemenkes, 2011).

Pemberian obat antiretroviral (ARV) lini pertama terdiri dari paduan 2 nucleoside atau nucleotide reverse transcriptase inhibitors (NRTI) serta 1 non-nucleoside reverse transcriptase inhibitors (NNRTI). Kombinasi antiretroviral merupakan dasar pelaksanaan pemberian terapi antiretroviral terhadap pasien HIV, karena dapat mengurangi resistensi, menekan replikasi HIV secara efektif sehingga penularan, infeksi oportunistik, dan komplikasi lainnya dapat dihindari serta meningkatkan kualitas dan harapan hidup dari pasien HIV. Terapi secara dini dapat melindungi sistem kekebalan tubuh dari kerusakan oleh virus HIV. Salah satu masalah yang muncul dari penggunaan obat antiretroviral (ARV) adalah efek samping obat. Munculnya efek samping ini sering menjadi alasan untuk mengganti (substitusi) dan atau menghentikan pengobatan ARV (Kemenkes, 2011). Efek samping minor akibat penggunaan ARV dapat mengakibatkan pasien tidak patuh untuk minum obat. Oleh karena itu, sangat penting bagi farmasis untuk terus melakukan konseling dan mendukung terapi ARV. Penelitian sebelumnya menyatakan bahwa efek samping yang sering dialami oleh pasien HIV adalah sakit kepala sebesar $34,73 \%$, alergi sebesar $21,05 \%$, dan mual muntah sebesar $17,90 \%$. 
Salah satu metode yang digunakan untuk mengevaluasi efek samping yaitu algoritma Naranjo. Kuesioner yang dirancang oleh Naranjo untuk menentukan apakah efek samping disebabkan oleh obat atau faktor lainnya. Kelebihan algoritma Naranjo ialah obat dievaluasi secara individual untuk kausalitas dan poin dapat dikurangi jika ada faktor lain yang mengakibatkan efek samping. Efek samping obat tidak boleh menjadi penghambat dimulainya terapi ARV. Perlu diingat bahwa tidak semua pasien akan mengalaminya dan efek samping yang timbul bisa diatasi dengan baik. Hal ini jauh lebih menguntungkan bila dibandingkan dengan risiko kematian yang akan terjadi bila pasien tidak mendapatkan terapi ARV (Kemenkes, 2011). Berdasarkan latar belakang tersebut, maka dilakukan penelitian yang bertujuan untuk mengkaji efek samping dan kausalitas penyebab efek samping akibat penggunaan obat ARV pada pasien HIV rawat jalan menggunakan algoritma Naranjo.

\section{Metode}

Penelitian ini merupakan penelitian prospektif observasional dengan desain penelitian cross-sectional. Pada penelitian ini pasien HIV rawat jalan hanya dilakukan observasi satu kali saja dengan dilakukan wawancara terkait efek samping penggunaan ARV menggunakan algoritma Naranjo. Penelitian ini telah dinyatakan laik etik oleh Komite Etik Rumah Sakit Bhayangkara H.S Samsoeri Mertojoso, Surabaya dengan nomor 01/I/2020/KEPK/RUMKIT. Penelitian berlangsung pada bulan Januari hingga Maret 2020.

\subsection{Populasi, sampel, dan teknik pengambilan sampel}

Populasi pada penelitian ini ialah pasien HIV rawat jalan baik pasien baru maupun pasien lama yang menjalani pengobatan di poli VCT Rumah Sakit Bhayangkara H.S Samsoeri Mertojoso. Sampel pada penelitian ini ialah pasien HIV rawat jalan yang memenuhi kriteria inklusi. Teknik pengambilan sampel menggunakan non-probability sampling dengan jenis consecutive sampling, dimana setiap pasien HIV rawat jalan yang menjalani pengobatan di poli VCT Rumah Sakit Bhayangkara H.S Samsoeri Mertojoso serta sesuai dengan kriteria inklusi akan diikutsertakan sebagai subyek penelitian. Besar sampel pada penelitian ini dihitung berdasarkan rumus proporsi cross-sectional satu kelompok sebagai berikut:

$$
\begin{gathered}
n=\frac{Z_{1-\alpha / 2}^{2} P(1-P) N}{d^{2}(N-1)+Z_{1-\alpha / 2}^{2} P(1-P)} \\
n=\frac{1,96^{2} \cdot 0,5+(1-0,5) \cdot 204}{0,1^{2}(204-1)+1,96^{2} \cdot 0,5(1-0,5)} \\
n=65,5 \cong 66 \\
n=66+10 \% \\
n=72 \text { subyek }
\end{gathered}
$$


Keterangan:

$\mathrm{n}=$ jumlah sampel; $\mathrm{N}=$ jumlah populasi; $\mathrm{P}=$ proporsi di populasi $\mathrm{d}=$ derajat akurasi $Z_{1-\alpha / 2}=$ nilai baku distribusi normal pada $\alpha$ tertentu

Diketahui bahwa pasien HIV yang menjalani rawat jalan di poli VCT sebesar 204 pasien. Dengan memasukan $\mathrm{P}=0,5, \mathrm{~d}=0,1$, dan $Z_{1-\alpha / 2}=1,96$, maka didapatkan jumlah minimal sampel yang harus diambil sebesar 72 pasien.

\subsection{Kriteria inklusi dan ekslusi}

Kriteria inklusi pada penelitian ini ialah pasien HIV rawat jalan; pasien HIV dengan usia 1765 tahun; pasien HIV yang mendapatkan terapi antiretroviral (ARV) lini pertama; dan pasien HIV yang bersedia menjadi subjek penelitian dengan mengisi informed consent. Terapi ARV lini pertama berupa paduan pilihan tenofovir (TDF) + lamivudine (3TC) + efavirenz (EFV) dalam bentuk fix dose combination, sedangkan paduan alternatif yaitu zidovudin (AZT), lamivudine (3TC) + efavirenz (EFV) atau tenofovir (TDF) + lamivudin (3TC) + nevirapin (NVP) (Kemenkes RI, 2015). Kriteria ekslusi pada penelitian ini ialah pasien HIV dengan kondisi hamil; pasien HIV yang disertai dengan penyakit autoimun lain seperti SLE dan rheumatoid arthritis (RA); dan pasien HIV yang tidak bisa berkomunikasi secara lisan maupun tulis.

\subsection{Pengambilan data}

Data yang dikumpulkan pada penelitian ini ialah data demografi pasien HIV yang meliputi usia, profil penyakit lain selain HIV, profil infeksi oportunistik, profil ARV, dan lama penggunaan ARV. Selain itu pula, dilakukan wawancara kepada pasien HIV terkait efek samping yang dirasakan oleh pasien selama pengobatan dengan ARV lini pertama menggunakan algoritma atau pedoman Naranjo. Efek samping yang diamati pada penelitian ini ialah efek samping yang dirasakan atau dikeluhkan oleh pasien yang diduga akibat penggunaan ARV lini pertama. Pada penelitian ini pertanyaan nomor 6, 7, dan 10 yang terdapat pada algoritma Naranjo tidak ditanyakan kepada pasien dikarenakan memerlukan pemeriksaan laboratorium dan pemberian plasebo.

\subsection{Analisis data}

Data efek samping yang merupakan data nominal dilakukan tabulasi dalam bentuk persentase. Setiap item pertanyaan pada algoritma Naranjo akan diberikan skor dan ditotal untuk selanjutnya akan diklasifikasikan menjadi total skor 0 (ragu-ragu/doubtful), 1-4 (cukup mungkin/possible), 5-8 (mungkin/probable), serta 9+ (sangat mungkin/highly probable) (BPOM, 2012). Untuk melihat perbedaan skor Naranjo antara pasien HIV dengan infeksi oportunistik dan tanpa infeksi oportunistik serta perbedaan skor Naranjo pada pasien HIV dengan dan tanpa penyakit penyerta dilakukan analisis statistik menggunakan independent $t$-test. Data dikatakan bermakna jika nilai signifikasi $\leq 0,05$. 


\section{Hasil dan pembahasan}

Pada penelitian ini didapatkan 72 pasien HIV rawat jalan yang menjalani rawat jalan yang memenuhi kriteria inklusi. Data demografi pasien HIV seperti ditunjukkan pada Tabel 1. Dari hasil penelitian didapatkan data bahwa pasien dengan jenis kelamin laki-laki lebih banyak dibandingkan perempuan. Hal ini sesuai dengan penelitian yang dilakukan oleh Puspasari et al. (2018) yang menyatakan bahwa pada pasien HIV, jenis kelamin laki-laki lebih banyak dibandingkan perempuan yaitu sebesar 69,2\% yang berasal dari kelompok gay, biseksual, dan transgender. Hal ini juga dikaitkan laki-laki lebih berisiko tinggi terlibat pada hubungan homoseksual, heteroseksual, dan penggunaan jarum suntik non-steril (Sari et al., 2018). Dalam penelitian ini didapatkan data bahwa usia pasien HIV rawat jalan berada dalam usia produktif dengan dengan usia rata-rata 29,9 $\pm 8,9$ tahun. Proporsi terbesar kasus HIV dan AIDS masih pada penduduk usia produktif 15-49 tahun (Kemenkes, 2019). Dari 72 pasien HIV rawat jalan, status pasien lama lebih banyak dibandingkan pasien baru. Pasien baru adalah pasien HIV yang pertama kali menggunakan obat antiretroviral, sedangkan pasien lama adalah pasien HIV yang pernah datang sebelumnya untuk keperluan pemeriksaan kembali (Wijaya \& Dewi, 2017).

Tabel 1. Karakteristik Pasien HIV Rawat Jalan ( $n=72$ )

\begin{tabular}{lc}
\hline Karakteristik & $\mathrm{n}(\%)$ \\
\hline Jenis Kelamin & $63(87)$ \\
Laki-Laki & $9(13)$ \\
Perempuan & \\
Usia (Tahun) & $17-53$ \\
Rentang & $29,9 \pm 8,9$ \\
Rata-rata \pm SD & \\
Kategori Usia & $33(46)$ \\
Remaja Akhir (17-25) & $21(29)$ \\
Dewasa Awal (26-35) & $12(17)$ \\
Dewasa Akhir (36-45) & $6(8)$ \\
Lansia Awal (46-55) & \\
Status Pasien & $2(3)$ \\
Pasien Baru & $70(97)$ \\
Pasien Lama & \\
ARV lini pertama & $63(57)$ \\
FDC (Efavirenz 600 mg, Lamivudin 300 mg, Tenofovir & $34(31)$ \\
300 mg) & $13(12)$ \\
Efavirenz 600 mg, Lamivudin 150 mg, Tenofovir 300 mg) & \\
Duviral (Zidovudin+Lamivudin)-Neviral (Nevirapin) & $13(18)$ \\
Lama Terapi ARV & $18(25)$ \\
1 Minggu - 5 Bulan & $41(57)$ \\
6 Bulan - 12 Bulan & \\
>1 Tahun & \\
\hline
\end{tabular}

Pada hasil penelitian didapatkan data bahwa sebanyak 13 pasien HIV rawat jalan disertai dengan infeksi oportunistik. Tuberkulosis paru adalah infeksi oportunistik yang paling banyak ditemukan dengan persentase sebesar 61\% diikuti oleh (PCP) sebesar 15\% seperti ditunjukkan pada Tabel 2. Tuberkulosis (TB) banyak ditemukan pada pasien HIV dikarenakan bakteri $M$. 
tuberkulosis dapat meningkatkan replikasi HIV-1 pada sel $\mathrm{T}$ atau makrofag dan terjadi peningkatan viral load (Pawlowski et al., 2012). Orang dengan HIV berisiko 19 kali lebih besar terkena penyakit tuberkulosis dibandingkan orang tanpa HIV (WHO, 2019). Dengan adanya TB pada pasien HIV akan memperburuk prognosis pasien yang dapat menyebabkan fungsi imunitas pasien semakin memburuk.

Tabel 2. Profil penyakit infeksi oportunistik pada pasien HIV ( $n=13)$

\begin{tabular}{clc}
\hline No. & \multicolumn{1}{c}{ Infeksi oportunistik } & n (\%) \\
\hline 1 & Tuberkulosis paru & $8(61)$ \\
2 & Pneumocystis pneumonia (PCP) & $2(15)$ \\
3 & Tuberkulosis ekstra paru & $1(8)$ \\
4 & Sifilis & $1(8)$ \\
5 & Kandidiasis oral & $1(8)$ \\
\hline
\end{tabular}

Pada penelitian ini obat yang digunakan untuk mengobati tuberkulosis adalah obat antituberkulosis (OAT) dengan persentase 69\% seperti yang ditunjukkan pada Tabel 3. Selain tuberkulosis, infeksi oportunistik lainnya yang ditemukan pada penelitian ini adalah Pneumocystis pneumonia (PCP) yang disebabkan oleh Pneumocystis jirovecii. Infeksi PCP terjadi sekitar 70\%$80 \%$ pada pasien HIV dan sekitar $90 \%$ kasus PCP terjadi pada pasien dengan jumlah sel CD $4^{+}<200$ $\mathrm{sel} / \mathrm{mm}^{3}$ (Health \& Services, 2018). Terapi yang digunakan untuk mengobati PCP pada penelitian ini adalah kotrimoksazol forte (trimetoprim dan sulfametoksazol), dikarenakan efektivitasnya yang tinggi, profil keamanan obat yang baik, biaya rendah dan spektrum antimikroba yang luas (Hof, 2012).

Tabel 3. Profil obat untuk infeksi oportunistik

\begin{tabular}{|c|c|c|}
\hline No. & Obat & n (\%) \\
\hline 1. & $\begin{array}{l}\text { FDC fase intensif (Rifampisin } 150 \mathrm{mg} \text {, Isoniazid } \\
75 \mathrm{mg} \text {, Pirazinamid } 400 \mathrm{mg} \text {, Etambutol HCl } \\
275 \mathrm{mg} \text { ) dan FDC fase lanjutan (Rifampisin } \\
150 \mathrm{mg} \text {, Isoniazid } 150 \mathrm{mg} \text { ) }\end{array}$ & $9(69)$ \\
\hline 2. & Sefiksim dan kotrimoksazol forte & $2(15)$ \\
\hline 3. & $\begin{array}{l}\text { Injeksi penicillin G prokain, eritromisin stearat } \\
500 \mathrm{mg} \text {, dan doksisiklin }\end{array}$ & $1(8)$ \\
\hline 4. & Flukonazol & $1(8)$ \\
\hline
\end{tabular}

Pada pasien HIV memerlukan perawatan dengan obat antiretroviral (ARV) dalam waktu yang panjang, bahkan seumur hidup (WHO, 2016). Hal ini bertujuan untuk menghambat replikasi virus HIV dan menekan viral load, meningkatkan kualitas hidup dan meningkatkan harapan masyarakat, sehingga saat ini HIV diterima sebagai penyakit yang dapat dikendalikan. Pada penelitian ini, digunakan terapi lini pertama yang terdiri dari 2 nucleoside atau nucleotide reverse transcriptase inhibitors (NRTI) dan 1 non-nucleoside reverse transcriptase inhibitors (NNRTI). Kombinasi ARV yang paling banyak digunakan dalam penelitian ini adalah dalam bentuk FDC (Efaviren 600mg, lamivudin 300mg, tenofovir 300mg) dengan persentase 57\%. Hal ini sesuai dengan penelitian sebelumnya yang menyebutkan bahwa kombinasi tenofovir, lamivudin dan 
efaviren lebih banyak digunakan dengan persentase $73,68 \%$. Hal ini dikarenakan obat dalam bentuk FDC memiliki efek samping yang minimal dan obat diminum satu kali sehari sehingga lebih mudah diterima oleh pasien HIV/AIDS yang bertujuan untuk meningkatkan kepatuhan pasien (Kemenkes, 2014).

Lebih lanjut diuraikan dalam penelitian ini, lama penggunaan obat ARV pada pasien HIV paling banyak adalah lebih dari 1 tahun dengan persentase 57\%. Hal ini sejalan dengan penelitian Shafiekhani et al. (2017) yang menyatakan bahwa lama penggunaan obat ARV pada pasien HIV paling banyak adalah lebih dari 1 tahun dengan persentase 54,5\%. Pada pasien HIV diharapkan setelah penggunaan ARV lebih dari 1 tahun dapat memperbaiki jumlah $\mathrm{CD}^{+}{ }^{+}$dengan terjadinya peningkatan jumlah $\mathrm{CD}^{+} \geq 500 \mathrm{sel} / \mathrm{mm}^{3}$. Berdasarkan hasil penelitian menunjukkan bahwa pasien HIV yang menjalani pergantian regimen ARV sebesar $17 \%$ dan pergantian ARV paling banyak dari kombinasi duviral dan neviral menjadi FDC (tenofovir, lamivudin, efaviren) sebesar 75\% seperti ditunjukkan pada Tabel 4. Hal ini dikarenakan timbulnya efek samping obat pada beberapa pasien seperti ruam kulit, mual, dan pusing. Pada pasien yang tidak mengalami penggantian regimen dikarenakan timbulnya efek samping obat masih dapat ditoleransi.

Tabel 4. Penggantian terapi ARV

\begin{tabular}{cllc}
\hline No & Regimen ARV awal & Perubahan regimen ARV & n (\%) \\
\hline \multirow{2}{*}{$\begin{array}{l}\text { FDC (Efaviren } \\
600 \mathrm{mg} \text {, lamivudin } \\
300 \mathrm{mg} \text {, tenofovir } \\
300 \mathrm{mg})\end{array}$} & Duviral dan neviral & $3(25)$ \\
2 & Duviral dan neviral & $\begin{array}{l}\text { FDC (Efaviren 600mg, } \\
\text { lamivudin } 300 \mathrm{mg}, \\
\text { tenofovir 300mg) }\end{array}$ & $9(75)$ \\
\hline
\end{tabular}

Pada penelitian ini didapatkan tiga jenis efek samping pada pasien HIV rawat jalan yang paling banyak terjadi adalah pusing, mual dan muntah, dan ruam seperti yang ditunjukkan pada Tabel 5.

Tabel 5. Profil efek samping obat ARV lini pertama

\begin{tabular}{|c|c|c|}
\hline No. & Jenis ESO & n (\%) \\
\hline 1 & Pusing & $56(46)$ \\
\hline 2 & Mual dan Muntah & 41 (33) \\
\hline 3 & Ruam & $15(12)$ \\
\hline 4 & Halusinasi & $5(4)$ \\
\hline 5 & Mengantuk & $4(3)$ \\
\hline 6 & Sakit Kepala & $1(1)$ \\
\hline 7 & Mimpi Buruk & $1(1)$ \\
\hline
\end{tabular}

Efek samping ARV dapat terjadi pada pasien HIV dalam beberapa minggu pertama setelah inisiasi hingga pada pemakaian lama. Kebanyakan efek samping ARV relatif tidak berat dan dapat diatasi dengan pemberian obat suportif untuk mengatasi efek samping, sehingga pasien HIV tetap dapat melanjutkan pengobatannya. Penelitian oleh Arisudhana et al. (2018) yang mengukur 
korelasi antara efek samping dengan tingkat kepatuhan pasien HIV rawat jalan, didapatkan bahwa efek samping yang paling banyak terjadi adalah pusing $(52,9 \%)$ kemudian mual $(47,1 \%)$. Efek samping pada sistem saraf pusat (SSP) seperti pusing, diduga kuat akibat pemberian obat golongan NNRTI yaitu efaviren dengan persentase 2-28\% (Corbett \& Dana, 2016). Penggunaan ARV efaviren dilaporkan efek samping terbanyak yaitu pusing sebesar 66\%. Gangguan gastrointestinal (GI) dapat terjadi pada golongan NRTI yaitu lamivudin berupa mual (15\%-33\%) dan muntah (13\%-15\%), sedangkan pada penggunaan ARV tenofovir efek samping yang dilaporkan berupa mual (8\%-20\%) dan muntah (2\%-13\%) (Aronson, 2015). Efek samping dermatologi seperti ruam kulit banyak terjadi dikarenakan pemberian NNRTI yaitu nevirapine (1\%-7\%) dan efavirenz (5\%-26\%) (Corbett \& Dana, 2016). Terjadinya ruam kulit yang disebakan oleh penggunaan nevirapine berkisar 3-20\% dan efavirenz sebesar 8,2\% (Aronson, 2015). Efek samping pada saluran pencernaan berupa mual, muntah dan diare dapat terjadi dalam beberapa minggu pertama setelah penggunaan ARV. Meskipun demikian, efek samping tersebut bersifat self-limiting dan dapat diobati dengan pengobatan simptomatik (Kemenkes, 2014).

Berdasarkan hasil penelitian, tidak semua pasien mendapatkan pengobatan untuk mengatasi efek samping, dari 72 pasien hanya 19 pasien yang mendapatkan obat untuk mengatasi efek samping. Pengobatan yang diberikan paling banyak berasal dari resep dokter (52\%) dibandingkan obat swamedikasi (48\%). Obat swamedikasi yang banyak digunakan adalah parasetamol (62\%) untuk mengatasi pusing dan antasida (23\%) untuk mengatasi mual dan muntah. Pada resep dokter obat yang paling banyak digunakan adalah loratadin (40\%) dan salep desoximethason (40\%) untuk mengatasi ruam kulit.

Dari hasil observasi efek samping menggunakan algoritma Naranjo, didapatkan sebesar 86\% pasien HIV mengalami efek samping dalam skala probabilitas probable, yaitu pada skor 5-8, yang mengindikasikan bahwa efek samping yang dirasakan oleh pasien HIV terjadi akibat penggunaan ARV seperti ditunjukkan pada Tabel 6. Dari data probable, skor 6 merupakan nilai tertinggi dengan persentase sebesar 53\% yang diikuti skor 5 dengan persentase $39 \%$ dan skor 8 dengan persentase 6\%. Hal ini sejalan dengan penelitian yang dilakukan oleh Mukherjee et al. (2017) yang menyatakan bahwa pada pasien HIV rawat jalan di negara India, didapatkan skor Naranjo efek samping yang paling banyak berada pada kategori probable dengan persentase 88\%.

Tabel 6. Hasil Skala Naranjo

\begin{tabular}{clc}
\hline No & \multicolumn{1}{c}{ Skala Naranjo } & n (\%) \\
\hline 1 & Highly Probable (>9) & $1(1)$ \\
\hline 2 & Probable (5-8) & $62(86)$ \\
\hline 3 & Possible (1-4) & $9(13)$ \\
\hline
\end{tabular}

Pada penelitian ini didapatkan rata-rata skor Naranjo pada pasien HIV dengan infeksi oportunistik (IO) adalah 4, yang termasuk pada kategori possible yang artinya cukup mungkin efek 
samping yang terjadi karena penggunaan obat antiretroviral, sedangkan pasien HIV tanpa infeksi oportunistik memiliki skor rata-rata 6 yang masuk pada kategori probable yang artinya mungkin efek samping tersebut terjadi karena penggunaan obat antiretroviral seperti ditunjukkan pada Tabel 7. Nilai rata-rata skor naranjo pasien HIV dengan infeksi oportunistik lebih kecil daripada nilai rata-rata skor naranjo pada pasien HIV tanpa infeksi oportunistik dikarenakan obat yang digunakan untuk pengobatan infeksi oportunistik memiliki efek samping yang sama atau serupa seperti halnya efek samping antiretroviral sehingga hal tersebut dapat mempengaruhi skor naranjo. Pada hasil uji beda menggunakan independent $t$-test terdapat perbedaan bermakna antara pasien HIV dengan infeksi oportunistik dan pasien HIV tanpa infeksi oportunistik $(\mathrm{P}<0,05)$.

Tabel 7. Perbedaan Skor Naranjo Pada Pasien HIV Dengan dan Tanpa Infeksi Oportunistik

\begin{tabular}{lccc}
\hline Kategori Naranjo & $\begin{array}{c}\text { Dengan IO } \\
\mathrm{n}(\%)\end{array}$ & $\begin{array}{c}\text { Tanpa IO } \\
\mathrm{n}(\%)\end{array}$ & $\boldsymbol{\alpha}$ \\
\hline Highly Probable $(\geq 9)$ & - & $1(2)$ & \\
\hline Probable (5-9) & $7(54)$ & $55(93)$ & \multirow{2}{*}{0,004} \\
\hline Posible (1-4) & $6(46)$ & $3(5)$ & \\
\hline Rata-rata \pm SD & $4 \pm 1,7$ & $6 \pm 1,2$ & \\
\hline
\end{tabular}

Pada penelitian ini, didapatkan bahwa pada pasien HIV dengan penyakit oportunistik, sebanyak 69\% pasien mendapatkan pengobatan obat antituberkulosis (OAT) lini pertama, 15\% pasien mendapatkan antibiotik sefiksim dan kotrimoksazol forte, dan 8\% pasien mendapatkan flukonazol. Beberapa pengobatan untuk infeksi oportunistik yang memiliki efek samping yang sama seperti antiretroviral adalah obat antituberkulosis rifampisin yang dapat menyebabkan mual dan muntah $(71,5 \%)$ serta rash pada kulit (28,5\%) (Musdalipah et al., 2018). Sefiksim yang digunakan untuk penyakit sifilis pada penelitian ini juga memiliki efek samping berupa mual (2\%10\%) (Corbett \& Dana, 2016). Efek samping kotrimoksazol forte untuk pengobatan PCP yaitu anemia (16,5\%), mual $(15,4 \%)$ dan muntah $(7,8 \%)$ (Mastini et al., 2017). Fluconazole pada penelitian yang digunakan untuk kandidiasis oral memiliki efek samping berupa mual dan muntah sebesar 10\%-15\% (Aronson, 2015). Efek samping mual dan muntah pada terapi ARV disebabkan oleh efavirenz, lamivudine, dan tenofovir. Adanya efek samping yang serupa antara OAT dengan ARV yang dikonsumsi oleh pasien HIV, akan menyebabkan nilai probabilitas Naranjo semakin kecil, yang artinya efek samping tersebut kemungkinan besar juga diakibatkan oleh OAT untuk tatalaksana pasien HIV dengan TB.

Pada pasien HIV dengan penyakit penyerta didapatkan nilai rata-rata 4 yang masuk pada kategori possible, dan skor rata-rata pasien HIV tanpa penyakit penyerta adalah 6 yang masuk pada kategori probable seperti ditunjukkan pada Tabel 8. Pada hasil uji beda menggunakan independent $t$-test terdapat perbedaan bermakna skor naranjo antara pasien HIV dengan penyakit penyerta dan pasien HIV tanpa penyakit penyerta $(\mathrm{P}<0,05)$. Pada penelitian ini, didapatkan hasil sebanyak 29\% pasien HIV disertai dengan penyakit penyerta dislipidemia, 29\% dengan hipotensi, 
serta gastritis, artritis, dan vertigo masing-masing sebesar 14\%. Dari data tersebut, hanya didapatkan data penggunaan obat betahistin untuk terapi vertigo. Efek samping dari betahistin yaitu sakit kepala, mual, dan rasa tidak nyaman pada saluran cerna (BNF, 2019). Adanya efek samping betahistin yang serupa dengan ARV, akan menyebabkan nilai probabilitas Naranjo semakin kecil, yang artinya efek samping mual dan rasa tidak nyaman pada saluran cerna tidak hanya diakibatkan oleh ARV, tetapi juga oleh terapi betahistin.

\begin{tabular}{lccc}
\multicolumn{4}{c}{ Tabel 8. Perbedaan skor Naranjo pada pasien HIV dengan dan tanpa penyakit penyerta } \\
\hline Kategori Naranjo & $\begin{array}{c}\text { Dengan penyakit } \\
\text { penyerta } \\
\text { n (\%) }\end{array}$ & $\begin{array}{c}\text { Tanpa penyakit } \\
\text { penyerta } \\
\text { n (\%) }\end{array}$ & $\boldsymbol{\alpha}$ \\
\hline Highly Probable $(\geq 9)$ & - & $1(2)$ & \\
\hline Probable (5-9) & $4(57)$ & $58(89)$ & 0,003 \\
\hline Posible (1-4) & $3(43)$ & $6(9)$ & \\
\hline Rata-rata \pm SD & $4 \pm 1,6$ & $6 \pm 1,2$ & \\
\hline
\end{tabular}

Keterbatasan pada penelitian ini adalah tidak dilakukan pemeriksaan berkala data lab penunjang seperti kadar BUN dan kreatinin untuk pemantauan efek samping toksisitas ginjal pada pasien yang menggunakan tenofovir. Selain itu keterbatasan lainnya ialah kurang adanya wawancara yang mendalam tentang pengobatan yang digunakan oleh pasien HIV selain pengobatan antiretroviral.

\section{Kesimpulan}

Berdasarkan penelitian tentang kajian efek samping obat antiretroviral pada pasien HIV rawat jalan menggunakan algoritma Naranjo dapat disimpulkan bahwa efek samping yang paling banyak dirasakan oleh pasien HIV berupa efek samping minor yang tidak memerlukan penghentian pengobatan serta efek samping yang dirasakan oleh pasien terbanyak berada pada kategori probable. Hal ini mengindikasikan bahwa efek samping tersebut sangat mungkin terjadi karena penggunaan obat antiretroviral lini pertama.

\section{Ucapan terima kasih}

Seluruh penulis mengucapkan terima kasih kepada seluruh staf di poli VCT Rumah Sakit Bhayangkara H.S. Samsoeri Mertojoso Surabaya yang telah membantu peneliti dalam melaksanakan penelitian ini.

\section{Konflik kepentingan}

Semua penulis menyatakan tidak ada konflik kepentingan dalam penelitian ini. 


\section{Daftar pustaka}

Arisudhana, G. A. B., Sofro, M. A. U., \& Sujianto, U. (2018). Antiretroviral Side Effects on Adherence in People Living with HIV/AIDS. Nurse Media Journal of Nursing, 8(2), 79-85. doi:https://doi.org/10.14710/nmjn.v8i2.20742

Aronson, J. K. (2015). Meyler's side effects of drugs: the International Encyclopedia of Adverse Drug Reactions and interactions. Oxford: Elsevier Science.

BNF. (2019). British National Formulary(78th ed). London, United Kingdom: Pharmaceutical Press.

BPOM. (2012). Pedoman Monitoring Efek Samping Obat (Meso) Bagi Tenaga Kesehatan. Jakarta: BPOM RI

Corbett, A. H., \& Dana, J. W. (2016). Drug information Handbook (25th Edition ed.). America: American Pharmacy Association.

Dipiro, J. T., Talbert, R. L., Yee, G. C., Matzke, G. R., Wells, B. G., \& Posey, L. M. (2017). Pharmacotherapy: A Pathophysiologic Approach (Tenth Edition ed.). New York, United States: McGraw-Hill Medical.

Health, H. D. t., \& Services, H. (2018). Guidelines for the use of antiretroviral agents in adults and adolescents living with HIV. In. doi:https://aidsinfo.nih.gov/guidelines/html/1/adult-andadolescent-treatment-guidelines

Hof, H. (2012). Pneumocystis jirovecii: a peculiar fungus posing particular problems for therapy and prophylaxis. Mycoses, 55(s1), 1-7. doi:https://doi.org/10.1111/j.14390507.2011.02159.x

Kemenkes. (2011). Pedoman Nasional Tatalaksana Infeksi HIV dan Terapi Antiretroviral pada Orang Dewasa. Jakarta: Direktorat Jendral Pengendalian Penyakit dan Penyehatan Lingkungan

Kemenkes. (2014). Peraturan Menteri Kesehatan Republik Indonesia Nomor 87 Tahun 2014 tentang Pedoman Pengobatan Antiretroviral. Jakarta: Kementerian Kesehatan RI

Kemenkes. (2019). Laporan Perkembangan HIV AIDS dan Infeksi Menular Seksual (IMS) Triwulan IV tahun 2018. Jakarta: Direkterat Jenderal Pencegah dan Pengendali Penyakit (P2P)

Mastini, K. A., Djoerban, Z., Yunihastuti, E., \& Shatri, H. (2017). Gambaran Pemberian Profilaksis Primer Kotrimoksazol pada Pasien HIV Dewasa di Unit Pelayanan Terpadu HIV RSCM Tahun 2004-2013. Jurnal Penyakit Dalam Indonesia, 4(4), 169-177. doi:http://dx.doi.org/10.7454/jpdi.v4i4.151

Mukherjee, S., Era, N., Saha, B., \& Tripathi, S. K. (2017). Adverse drug reaction monitoring in patients on antiretroviral therapy in a tertiary care hospital in Eastern India. Indian journal of pharmacology, 49(3), 223-228. doi:https://doi.org/10.4103/ijp.IJP_304_16

Musdalipah, M., Nurhikma, E., Karmilah, K., \& Fakhrurazi, M. (2018). Efek Samping Obat Anti Tuberkulosis (Oat) dan Penanganannya pada Pasien Tuberkulosis (Tb) di Puskesmas Perumnas Kota Kendari. Jurnal Ilmiah Manuntung, 4(1), 67-73.

Pawlowski, A., Jansson, M., Sköld, M., Rottenberg, M. E., \& Källenius, G. (2012). Tuberculosis and HIV co-infection. PLoS Pathog, 8(2), e1002464. doi:https://doi.org/10.1371/journal.ppat.1002464

Puspasari, D., Wisaksana, R., \& Rovina, R. (2018). Gambaran Efek Samping dan Kepatuhan Terapi Antiretroviral pada Pasien HIV di Rumah Sakit Dr. Hasan Sadikin Bandung tahun 2015. Jurnal Sistem Kesehatan, 3(4). doi:https://doi.org/10.24198/jsk.v3i4.18495

Sari, S. P., Isnaini, S. R., \& Puspitasari, A. W. (2018). Monitoring side effects of antiretroviral therapy in patients with human immunodeficiency virus/acquired immunodeficiency syndrome. International Journal of Applied Pharmaceutics, 10(1), 321-324. doi:https://doi.org/10.22159/ijap.2018.v10s1.71

Shafiekhani, M., Karimi, S., ali Davarpanah, M., \& Vazin, A. (2017). Evaluating drug interactions, adverse drug reactions, and level of adherence to highly active antiretroviral therapy regimen amongst HIV-positive patients who referred to an AIDS healthcare center in fars, Southern Iran: The first multifaceted study from Iran. HIV AIDS Review, 16(1), 24-31. doi:https://doi.org/10.5114/hivar.2017.65334 
WHO. (2016). Consolidated guidelines on the use of antiretroviral drugs for treating and preventing HIV infection: recommendations for a public health approach, 2nd ed.: World Health Organization.

WHO. (2019). Global Tuberculosis Report 2019. Geneva: World Health Organization.

Wijaya, L., \& Dewi, D. R. (2017). Manajemen Informasi Kesehatan II: Sistem dan Sub Sistem Pelayanan RMIK. In (pp. 332). 